\title{
Prediction values for the ventilatory capacity in male West Pakistani workers in the United Kingdom
}

\author{
M.A. MALIK ${ }^{1}$, E. MOSS, and W. R. LEE \\ Department of Occupational Health, University of Manchester
}

The ventilatory functions (forced vital capacity, forced expiratory volume in one second, and peak expiratory flow rate) of West Pakistani immigrants working near Manchester were measured. There were 198 'normal' healthy adult workers aged 25 to 60 years and 129 workers aged 16 to 24 years. The subjects were considered ' normal' if they did not admit to persistent cough and phlegm. The regression equations on age and height for the two groups are presented together with the corresponding nomograms for the adult group.

Ventilatory function reached its maximum between the ages of 25 and 30 years; smokers and dust-exposed subjects did not differ significantly from non-smokers and non-dust-exposed subjects $(P>0 \cdot 1)$. This was probably due to their relatively light smoking habits and the short duration of dust exposure. The effects of age, in workers over the age of 25 years, and the predominant effects of height on the FVC, FEV ${ }_{1 \cdot 0}$, and PEFR are similar to those found in other studies.

The ventilatory capacity of the subjects was found to be somewhat lower than that of Caucasians, about equal to that of Negroes living in America, and higher than that of Indians of Asian origin living in Guyana or of Bantu Negroes in South Africa.

The predicted FEV $_{1.0} /$ FVC $\%$ in the West Pakistani subjects is a little higher than any calculated from the results of other authors, but its regression on age is consistent with the findings of other studies and, therefore, can be used in clinical practice to assess the pulmonary conductance.

Ventilatory function testing is important in the assessment of pulmonary disability, but the normal values may differ widely from one ethnic group to another (Myers, 1925; Abramowitz, Leiner, Lewis, and Small, 1965; Cotes, 1968 ; Hearn, 1968; Miller, Ashcroft, Swan, and Beadnell, 1970). Indeed, with adequate numbers, epidemiological studies of ventilatory capacity may be used as an indication of differences between population groups (Lowe and his coworkers, 1968).

Up to the present, most studies have been done on American and European subjects. No such study has hitherto been published on the normal values of forced vital capacity, forced expiratory volume, and peak expiratory flow rate in male West Pakistani subjects living either in Pakistan or in the United Kingdom.

In this paper we describe how we collected information about the respiratory symptoms, 1Present address: Institute of Hygiene and Preventive Medicine,
6 Birdwood Road, Lahore, West Pakistan ventilatory capacity, physique, smoking habits, and occupational and social histories of West Pakistani male employees in 11 factories (5 industries) near Manchester, most of whom had been in the U.K. for 10 years or less. An account of how the field work was organized is a necessary prerequisite to the presentation of our results. Because the survey was the first of its kind on this ethnic group, this account of the field work could also be of general interest.

\section{METHODS AND MATERIALS}

Three hundred and seventy-one Urdu-speaking subjects from West Pakistan between the ages of 16 and 60 years, working in three cotton textile mills at Shaw (Lancashire), five woollen mills at Slaithwaite (Yorkshire), an asbestos textile spinning mill at Rochdale (Lancashire), and a cable and a rubber manufacturing works at Manchester, were studied in the survey.

AGE ASCERTAINMENT Some of the subjects interviewed were ignorant of their exact age. Even the age on a passport was not reliable in certain cases. When un- 
certainty existed the subjects were questioned about the important events (such as partition of India in 1947) during their early years, and an estimate was then made from their replies.

ORGANIZATION OF FIELD WORK A preliminary visit to each factory was made to learn the administrative routine. Leaflets in Urdu and English were given to the Personnel Department for each subject in the population and the social leaders were informed about the objectives and usefulness of the survey. Both the managements and the representatives of the workers were assured that the information obtained would be treated as confidential and would in no way jeopardize the prospects of employment of the workers. It was gratifying that full co-operation was obtained by this procedure.

ADMINISTRATION OF MRC QUESTIONNAIRE The Medical Research Council short questionnaire on respiratory symptoms (MRC, 1960 and 1965) was used with the addition of a series of questions to elicit each man's occupational and residential history. This questionnaire has previously been translated into languages other than English and tested successfully (Olsen and Gilson, 1960) but not into Urdu. It was translated into Urdu, the common language of West Pakistan by M.A.M. In order to ensure that the original sense of the questions was not lost, the Urdu version was retranslated into English by a translator with no previous knowledge of the questionnaire. A few questions did not translate back into English exactly as the original. All points of difference were discussed by two of us (W.R.L. and M.A.M.) in company with the translator and the Urdu version was amended to convey the original sense of the question. The Urdu version of the questionnaire was tested on four Pakistani trainee teachers and four West Pakistani workers. It was repeated one month later on the same subjects who gave practically identical answers (Malik, 1971).

One of us (M.A.M.) speaks Urdu and could communicate directly with the subjects. All the questionnaires were administered and all the measurements made by him. Clinical examination was not performed. The subjects under study were defined as 'normal' if they did not admit to persistent cough and phlegm in answer to questions 6 and 10 of the MRC questionnaire on respiratory symptoms:

Q 6 Do you usually bring up any phlegm from your chest first thing in the morning in winter?

Q10 Do you bring up phlegm like this on most days for as much as three months each year?

population AND SAMple By custom, only male Pakistanis go to work, therefore the study was confined to male West Pakistani subjects. Out of 291 subjects examined at Shaw and Slaithwaite, 140 were in the age range 16-24 years, therefore in the other factories which were studied later we asked for volunteers over the age of 25 years.

The criterion of exposure to dust, irritant gases, and chemical fumes was based simply on the answer 'yes' to either question:
Q1 Have you ever worked in a dusty occupation?

Q2 Have you ever worked in or been exposed to irritant gases or chemical fumes?

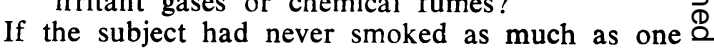

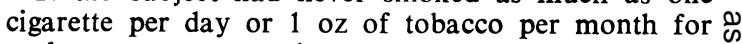
as long as one year, he was rated as a non-smoker. Subjects working in dusty conditions and those who. said they had been exposed to dust or chemical fumes $\overrightarrow{\vec{H}}$ as defined above and those who smoked were not $\stackrel{\omega}{\sim}$ excluded from the group used to establish prediction $\overrightarrow{\vec{x}}$ values, provided they did not suffer from persistent $x$ cough and sputum. Initially they were considered N separately to see whether their ventilatory capacity ir differed from those with no history of exposure to 9 dust and from those who did not smoke.

MEASUREMENTS The methods employed to obtain $\frac{\text { ㅇ }}{3}$ information on physical measurements were largely $\vec{C}$ those recommended by Weiner and Lourie (1969). $\mathbb{D}$ Before weights and heights were taken the subjects removed headgear, overcoats, and footwear.

For measurements of ventilatory capacity the sub- $\frac{0}{0}$ jects were seated and had the test explained and demonstrated. Nose clips were not used because by $\vec{\varphi}$ running a series of tests with and without nose clips N early in the investigation it was found that performance was not altered by their use; rather their use made the subject nervous.

The nomenclature proposed by Gandevia and HughJones (1957) has been adopted as an extension of the nomenclature suggested by the Pappenheimer Com- $\mathbb{D}$ mittee (Pappenheimer, 1950).

Forced expiratory volume in one second $\left(\mathrm{FEV}_{1.0}\right) \overrightarrow{\overrightarrow{0}}$ and forced vital capacity (FVC) were measured by 3 means of a Garthur Vitalograph (dry spirometer) and peak expiratory flow rate (PEFR) by a Wright peak? flow meter. The Vitalograph was calibrated before, during, and at the end of the survey. Five tests were made with each subject and the mean of the two highest measurements was taken as the most represen- $x$ tative of the subject's ability. The ambient temperature was recorded for each set of tracings taken during the survey. The readings of the FEV 1.0 and FVC were corrected to body temperature and pressure saturated with water vapour (BTPS).

The PEFR, as defined by Wright and McKerrow $D$ (1959), was recorded by the peak flow meter in litres per minute. Again the mean of the two highest measurements was taken. The instrument is cheap, of portable, and simple to use. One object of using it $N$ in these tests was to assess its usefulness on this ethnic group and so to determine whether the instrument $\omega$ could be used to assess ventilatory function in certain remote areas of West Pakistan.

\section{RESULTS}

Of the 371 subjects examined, 327 were 'normal' as defined previously; 129 were aged 16 to $24 \stackrel{\mathrm{D}}{\mathrm{D}}$ years and 198 aged 25 to 60 years. Of the $\frac{\mathbb{P}}{\mathbb{D}}$ 'normal' workers aged 25 to 60 years, 127 were from the cotton and woollen mills where the re-? 
sponse rate was $98 \%$. The remaining 71 in this age group were volunteers from the asbestos, rubber, and cable works. The two groups were, however, closely similar in the simple regressions of FVC, FEV 1.0 , and PEFR on age and on standing height and they were not, therefore, considered separately. The age distribution of the population of this survey is shown in Table $I$.

T A B LE I

AGE DISTRIBUTION OF POPULATION OF THIS SURVEY

\begin{tabular}{|c|c|c|c|c|c|c|}
\hline \multirow[t]{2}{*}{$\begin{array}{c}\text { Age } \\
\text { Group } \\
\text { (years) }\end{array}$} & \multicolumn{2}{|c|}{$\begin{array}{l}\text { At Cotton \& } \\
\text { Woollen Mills, } \\
\text { Shaw \& } \\
\text { Slaithwaite }\end{array}$} & \multicolumn{2}{|c|}{$\begin{array}{l}\text { At Asbestos Mill, } \\
\text { Rochdale, \& } \\
\text { Cable \& Rubber } \\
\text { Works, } \\
\text { Manchester }\end{array}$} & \multicolumn{2}{|c|}{ Totals } \\
\hline & 'Normal' & $\begin{array}{c}\text { Not } \\
\text { 'Normal' }\end{array}$ & 'Normal' & $\begin{array}{c}\text { Not } \\
\text { 'Normal' }\end{array}$ & Normal' & $\begin{array}{c}\text { Not } \\
\text { 'Normal' }\end{array}$ \\
\hline $\begin{array}{l}16-19 \\
20-24\end{array}$ & $\begin{array}{r}100 \\
29\end{array}$ & $\begin{array}{l}8 \\
3\end{array}$ & 二 & 二 & $\begin{array}{r}100 \\
29\end{array}$ & $\begin{array}{l}8 \\
3\end{array}$ \\
\hline $\begin{array}{l}\text { Total } \\
16-24\end{array}$ & 129 & 11 & - & - & 129 & 11 \\
\hline $\begin{array}{c}25-29 \\
30-34 \\
35-39 \\
40-44 \\
45-49 \\
50-54 \\
55-59 \\
60\end{array}$ & $\begin{array}{r}23 \\
37 \\
32 \\
16 \\
7 \\
9 \\
3 \\
0\end{array}$ & $\begin{array}{l}0 \\
3 \\
5 \\
6 \\
7 \\
1 \\
2 \\
0\end{array}$ & $\begin{array}{r}9 \\
21 \\
18 \\
6 \\
5 \\
9 \\
2 \\
1\end{array}$ & $\begin{array}{l}1 \\
5 \\
0 \\
2 \\
1 \\
0 \\
0 \\
0\end{array}$ & $\begin{array}{r}32 \\
58 \\
50 \\
22 \\
12 \\
18 \\
5 \\
1\end{array}$ & $\begin{array}{l}1 \\
8 \\
5 \\
8 \\
8 \\
1 \\
2 \\
0\end{array}$ \\
\hline $\begin{array}{l}\text { Total } \\
25-60\end{array}$ & 127 & 24 & 71 & 9 & 198 & 33 \\
\hline $\begin{array}{l}\text { Total } \\
16-60\end{array}$ & 256 & 35 & 71 & 9 & 327 & 44 \\
\hline
\end{tabular}

A scatter diagram of FVC against age (Fig. 1) shows that up to about 25 years of age the FVC increased and thereafter decreased slowly. Broadly similar diagrams were obtained for

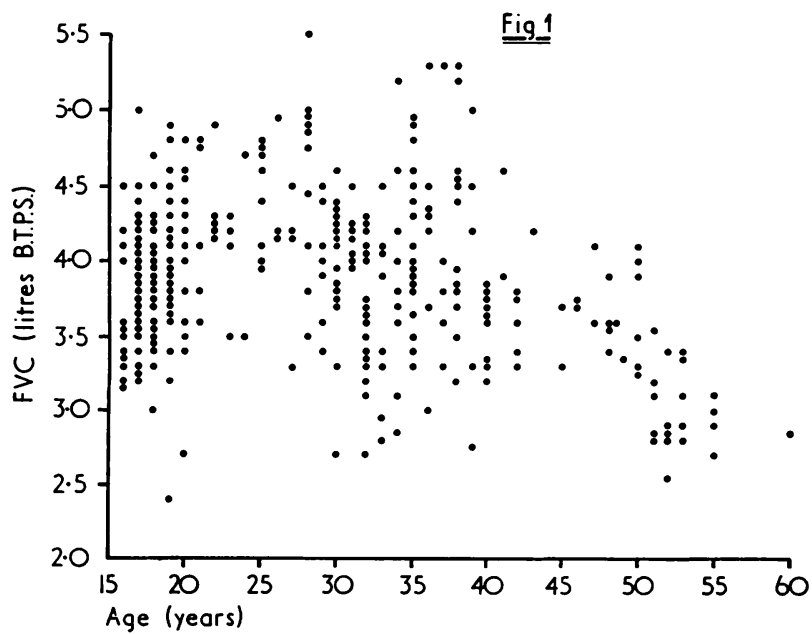

FIG. 1. Scatter diagram of FVC and age.

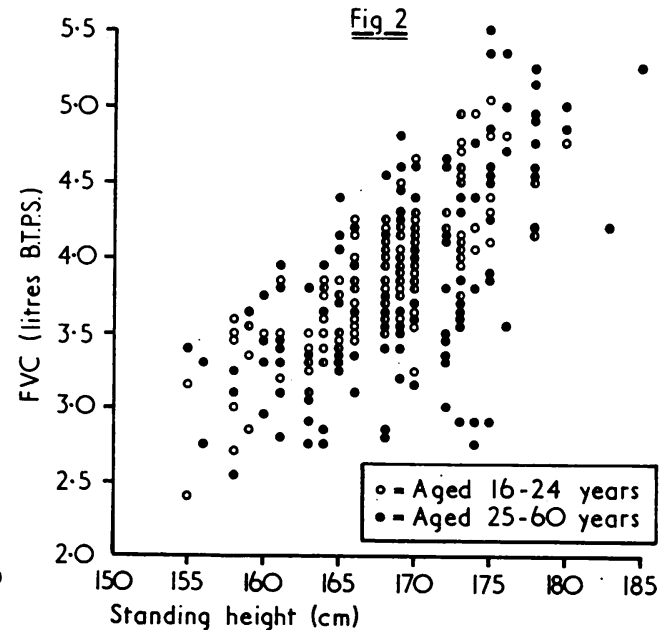

FEV $_{1.0}$ and PEFR against age. Similar observations have recently been reported by Walker, Archibald, and Attfield (1971). On the other hand, there was little change in height with age (see correlation coefficients in Tables III and VI). It was therefore decided to treat the younger subjects (16 to 24 years) separately, because of their apparent immaturity in lung function.

The FVC increased steadily with standing height over the whole age range 16 to 60 years (Fig. 2). The corresponding scatter diagrams for FEV $_{1.0}$ and PEFR against height are similar.

ADULT MALES AGED 25 TO 60 yeARS Four measurements were available for predicting ventilatory capacity - age, standing height, sitting height, and weight. Four indices of ventilatory capacity were considered-FVC, FEV ${ }_{1.0}$, FEV $_{1.0} /$ FVC\%,

T A B L E I I

PHYSICAL CHARACTERISTICS OF 198 'NORMAL' SUBJECTS AGED 25 TO 60 YEARS

\begin{tabular}{|c|c|c|c|c|c|}
\hline Variable & $\mathbf{n}$ & Mean & Range & $\begin{array}{l}\text { Standard } \\
\text { Deviation }\end{array}$ & $\begin{array}{c}\text { Coefficient } \\
\text { of } \\
\text { Variation } \\
\%\end{array}$ \\
\hline Age (years) & 198 & $36 \cdot 71$ & $25-60$ & $7 \cdot 96$ & $21 \cdot 7$ \\
\hline $\begin{array}{l}\text { Standing height } \\
\text { (cm) }\end{array}$ & 198 & $169 \cdot 07$ & $155-185$ & $5 \cdot 35$ & $3 \cdot 2$ \\
\hline $\begin{array}{l}\text { Sitting height } \\
\text { (cm) } \\
\text { Weight (kg) } \\
\text { FVC (litres) } \\
\text { FEV } \\
\text { FEV (litres) }\end{array}$ & $\begin{array}{l}198 \\
198 \\
198 \\
198\end{array}$ & $\begin{array}{r}86 \cdot 68 \\
66 \cdot 58 \\
3.89 \\
3 \cdot 30\end{array}$ & $\begin{array}{c}80-96 \\
43-95 \\
2 \cdot 57-5 \cdot 48 \\
2 \cdot 19-4 \cdot 82\end{array}$ & $\begin{array}{l}3.04 \\
9 \cdot 38 \\
0 \cdot 60 \\
0.55\end{array}$ & $\begin{array}{r}3 \cdot 5 \\
14 \cdot 1 \\
15 \cdot 5 \\
16 \cdot 5\end{array}$ \\
\hline$\frac{\mathrm{FEV}_{1 \cdot 0}}{\mathrm{FVC}} \%$ & 198 & $84 \cdot 81$ & $74 \cdot 9-97 \cdot 4$ & 3.84 & $4 \cdot 5$ \\
\hline $\begin{array}{l}\text { e (years } \\
\text { anding h }\end{array}$ & 192 & $36 \cdot 84$ & $25-60$ & 8.02 & $21 \cdot 8$ \\
\hline $\begin{array}{l}\text { Standing height } \\
\quad(\mathrm{cm}) \\
\text { PEFR (1./min) }\end{array}$ & $\begin{array}{l}192 \\
192\end{array}$ & $\begin{array}{l}169 \cdot 07 \\
467.94\end{array}$ & $\begin{array}{l}155-185 \\
293-630\end{array}$ & $\begin{array}{r}5 \cdot 36 \\
60 \cdot 02\end{array}$ & $\begin{array}{r}3 \cdot 2 \\
12 \cdot 8\end{array}$ \\
\hline
\end{tabular}

FIG. 2. Scatter diagram of FVC and standing height. 
T A B L E I I I

ZERO ORDER CORRELATION COEFFICIENTS FOR VARIABLES TAKEN IN PAIRS FOR 198 'NORMAL' SUBJECTS AGED 25 TO 60 YEARS $(n=192$ FOR PAIRS WITH PEFR)

\begin{tabular}{|c|c|c|c|c|c|c|c|c|}
\hline & FVC & $\mathrm{FEV}_{1 \cdot 0}$ & $\frac{\mathrm{FEV}_{1.0}}{\mathrm{FVC}} \%$ & PEFR & Age & $\begin{array}{c}\text { Standing } \\
\text { Height }\end{array}$ & $\begin{array}{l}\text { Sitting } \\
\text { Height }\end{array}$ & Weight \\
\hline $\begin{array}{l}\text { FVC } \\
\text { FEV }_{1 \cdot 0}\end{array}$ & 1 & $\begin{array}{l}0.96 \\
1\end{array}$ & $\begin{array}{l}0 \cdot 11 \\
0 \cdot 37\end{array}$ & $\begin{array}{l}0.64 \\
0.72\end{array}$ & $\begin{array}{l}-0.52 \\
-0.61\end{array}$ & $\begin{array}{l}0.63 \\
0.59\end{array}$ & $\begin{array}{l}0.57 \\
0.56\end{array}$ & $\begin{array}{l}0.08 \\
0.08\end{array}$ \\
\hline $\mathrm{FEV}_{1 \cdot 0} / \mathrm{FVC}^{\circ} \%$ & & & 1 & 0.46 & -0.48 & $-0 \cdot 05$ & 0.06 & $-0 \cdot 10$ \\
\hline $\begin{array}{l}\text { PEFR } \\
\text { Age } \\
\text { Standing height } \\
\text { Sitting height } \\
\text { Welght }\end{array}$ & & & & 1 & $\begin{array}{c}-0.53 \\
1\end{array}$ & $\begin{array}{c}0 \cdot 38 \\
-0 \cdot 11 \\
1\end{array}$ & $\begin{array}{r}0.42 \\
-0.14 \\
0.84 \\
1\end{array}$ & $\begin{array}{r}-0.02 \\
0.18 \\
0.45 \\
0.48 \\
1\end{array}$ \\
\hline
\end{tabular}

With 198 pairs of data the conficence level is $99 \%$ at about $r=0 \cdot 18$; values of $r$ not statistically significant at this level in bold type.

and PEFR. The mean values, ranges, standard deviations, and coefficients of variation of these eight variables are given in Table II.

The zero order correlation coefficients of all the variables taken in pairs are shown in Table III. The FVC, FEV $V_{1 \cdot 0}$, and PEFR are significantly correlated with age and with height but not with weight. $\mathrm{FEV}_{1 \cdot 0} / \mathrm{FVC} \%$ is significantly correlated with age but not with height or weight.

PEFR is highly correlated with $\mathrm{FEV}_{1 \cdot 0}(\mathrm{r}=0.72)$ but its correlation coefficients with age and height, though significant, are somewhat lower than those of FEV $_{1 \cdot 0}$. PEFR has a rather lower coefficient of variation than $\mathrm{FEV}_{1 \cdot 0}$ (Table II).

It was decided to base the prediction of ventilatory capacity on age and standing height. In our measurements standing height was found to be easier and quicker to measure and more reproducible than sitting height, as has already been pointed out by Cotes (1968) and by Lowe and his co-workers (1968). Standing height shows a very high association with sitting height (Table III, $\mathrm{r}=0.84, \mathrm{n}=198, \mathrm{P}<0.001$ ).

The subjects of the survey differed in occupational dust exposure and in smoking habits. To determine whether there was any difference between dust-exposed and non-dust-exposed smokers and non-smokers, the 198 subjects aged 25 to 60 years were classified into three groups:
(a) dust-exposed smokers
82
(b) dust-exposed non-smokers

(c) non-dust-exposed smokers and non-smokers

$15) 52 \stackrel{\mathbb{D}}{D}$

The simple regressions of FVC on age and on $\underset{\mathbb{D}}{2}$ standing height are very similar for the three 3 groups and $t$ tests showed no statistically sig- $\stackrel{\Phi}{-}$ nificant differences in the regression coefficients for the different groups $(P>0.1$ in all comparisons). The simple regressions of $\mathrm{FEV}_{1.0}$ and PEFR on age and on standing height are also very similar for the three groups $(P>0 \cdot 1$ in all comparisons of regression coefficients). The groups were, therefore, combined for further analysis.

Regression analysis The multiple regression equations for each of the four indices of ventilatory capacity on age and standing height are shown in Table IV together with the standard error of estimate and the multiple correlation coefficient (R). The multiple regression coefficient of $\mathrm{FEV}_{1.0} / \mathrm{FVC} \%$ on standing height was not significantly different from zero $(t=1 \cdot 60$, df 195 , $P>0 \cdot 1)$ so for this index standing height was discarded and the simple regression equation on age only was substituted.

Nomograms to facilitate the calculation of predicted values of FVC, FEV 1.0 , and PEFR from age and standing height are given in Figure 3.

SUBJECTS AGED 16 TO 24 YEARS As mentioned ? above, the younger subjects (aged 16 to 24 years)

T A B LE I V

MULTIPLE REGRESSION OF VENTILATORY CAPACITY ON AGE AND STANDING HEIGHT FOR 198 'NORMAL' SUBJECTS AGED 25 TO 60 YEARS

\begin{tabular}{|c|c|c|c|c|c|}
\hline $\mathbf{n}$ & $\begin{array}{l}\text { Index of Ventilatory } \\
\text { Capacity }\end{array}$ & & $\begin{array}{l}\text { Regression on Age (yr) } \\
\text { and Height }(\mathrm{cm})\end{array}$ & S.E. of Estimate & $\mathbf{R}$ \\
\hline $\begin{array}{l}198 \\
198 \\
198 \\
192\end{array}$ & $\begin{array}{l}\text { FVC (litres) } \\
\text { FEV } 1 \cdot 0 \text { (litres) } \\
\text { FEV } 1 \cdot 0 \text { FVC \% } \\
\text { PEFR (1./min) }\end{array}$ & $\begin{array}{l}= \\
= \\
=\end{array}$ & $\begin{array}{l}-5.98-0.034 \text { Age }+0.066 \mathrm{Ht} . \\
-4.38-0.038 \text { Age }+0.054 \mathrm{Ht} \text {. } \\
93.34-0.23 \text { Age } \\
-16.34-3.72 \text { Age }+3.67 \text { Ht. }\end{array}$ & $\begin{array}{l}0 \cdot 38 \\
0 \cdot 33 \\
3 \cdot 37 \\
47 \cdot 2\end{array}$ & $\begin{array}{l}0.78 \\
0.80 \\
-0.48(\mathrm{r}) \\
0.62\end{array}$ \\
\hline
\end{tabular}


Prediction values for the ventilatory capacity in male West Pakistani workers in the U.K. 615

Age in

yeors

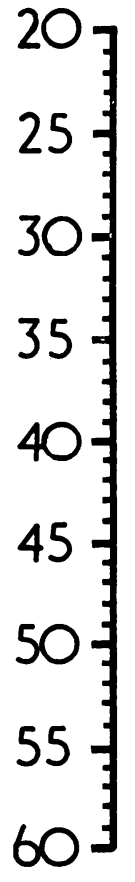

Standing height

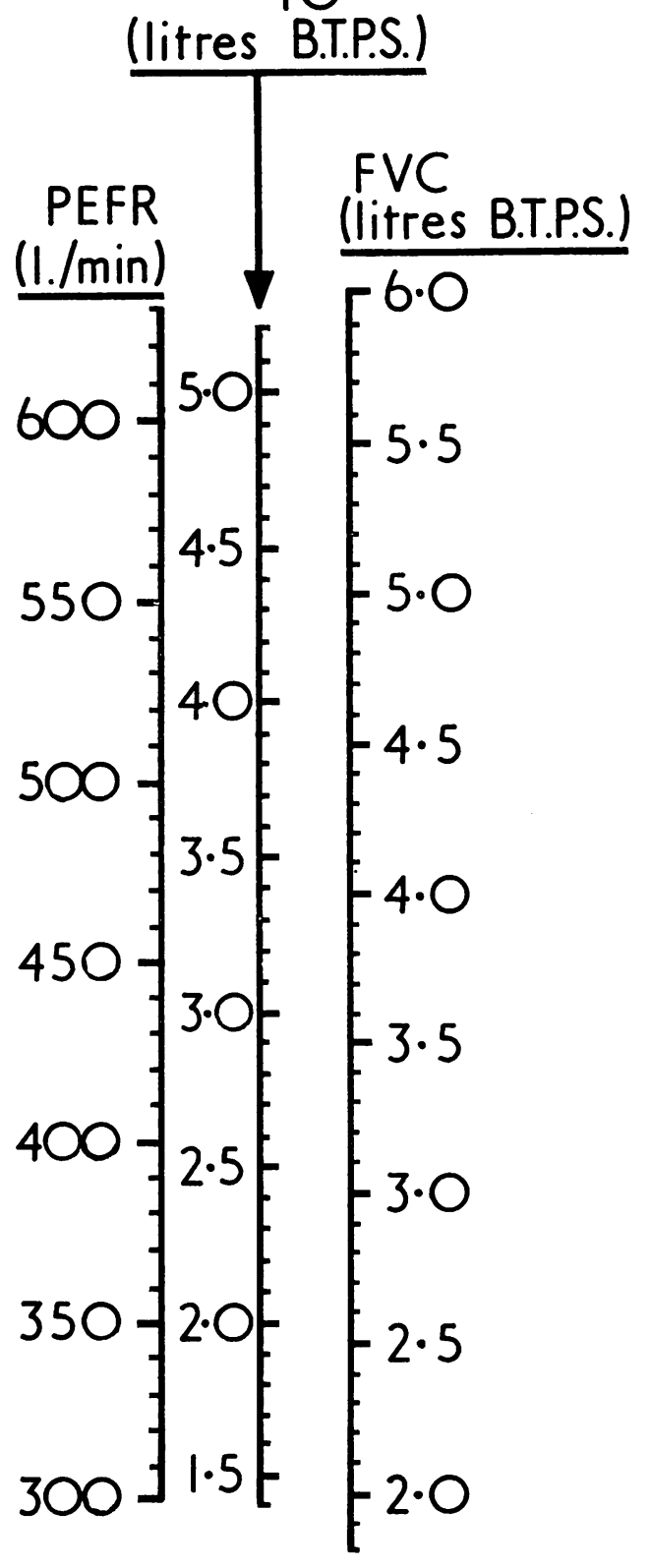

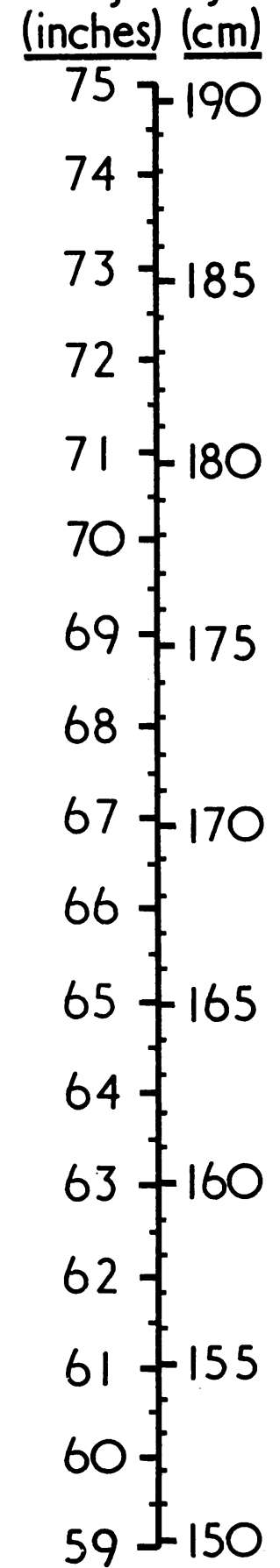

FIG. 3. Nomograms for FVC, FEV 1.0, and PEFR pre dicted from age and standing height for West Pakistanis aged 25 to 60 years. 
T A B L E V

PHYSICAL CHARACTERISTICS OF 129 'NORMAL' SUBJECTS AGED 16 TO 24 YEARS

\begin{tabular}{|c|c|c|c|c|}
\hline Variable & Mean & Range & $\begin{array}{l}\text { Standard } \\
\text { Deviation }\end{array}$ & $\begin{array}{c}\text { Coefficient } \\
\text { of Variation } \\
\%\end{array}$ \\
\hline $\begin{array}{l}\text { Age (years) } \\
\text { Standing height }(\mathrm{cm}) \\
\text { Sitting height (cm) } \\
\text { Weight (kg) } \\
\text { FVC (litres) } \\
\text { FEV } 1 \cdot 0 \text { (litres) } \\
\text { FEV } \\
\text { PEF (1./FVC \% } \\
\text { PER) }\end{array}$ & $\begin{array}{r}18 \cdot 51 \\
168.03 \\
85 \cdot 48 \\
57 \cdot 70 \\
3.91 \\
3 \cdot 56 \\
90 \cdot 96 \\
464 \cdot 00\end{array}$ & $\begin{array}{c}16-24 \\
155-180 \\
79-91 \\
45-84 \\
2 \cdot 40-5 \cdot 04 \\
2 \cdot 29-4 \cdot 65 \\
83 \cdot 4-97 \cdot 1 \\
330-590\end{array}$ & $\begin{array}{r}1 \cdot 79 \\
4.92 \\
2 \cdot 76 \\
7 \cdot 52 \\
0 \cdot 47 \\
0 \cdot 44 \\
2 \cdot 87 \\
55 \cdot 50\end{array}$ & $\begin{array}{r}9 \cdot 7 \\
2 \cdot 9 \\
3 \cdot 2 \\
13 \cdot 0 \\
12 \cdot 0 \\
12 \cdot 3 \\
3 \cdot 2 \\
12 \cdot 0\end{array}$ \\
\hline
\end{tabular}

have been considered separately because of their apparent immaturity in lung function. The mean values, ranges, standard deviations, and coefficients of variation of the eight variables for this younger group are given in Table $\mathrm{V}$, and the zero order correlation coefficients of all the variables taken in pairs are shown in Table VI. FVC, $\mathrm{FEV}_{1 \cdot 0}$, and PEFR show good correlation with height, but the correlations with weight and particularly with age are poor. The mean standing height $(168.03 \mathrm{~cm})$ is very close to that for the 198 adults aged 25 to 60 years $(169 \cdot 1 \mathrm{~cm}$, Table II). $\mathrm{FEV}_{1 \cdot 0} / \mathrm{FVC}^{\circ} \%$ is not significantly correlated with age, height or weight.

Regression analysis The multiple regression equations for each of the four indices of ventilatory capacity on age and standing height were calculated. For FVC and $\mathrm{FEV}_{1 \cdot 0}$ the multiple re- gression coefficients on age did not differ signifi- $\frac{\mathrm{C}}{\mathrm{O}}$ cantly from zero $(\mathrm{df}=126 ; \mathrm{FVC}, t=1 \cdot 3, \mathrm{P}>0 \cdot 1$; $\overline{\bar{\omega}}$ $\mathrm{FEV}_{1 \cdot 0}, t=0.4, \mathrm{P}>0.6$ ) so the simple regressions on standing height alone have been used. The regression equations for calculating the predic- on ted values of FVC, $\mathrm{FEV}_{1 \cdot 0}$, and PEFR are given $\vec{\circ}$ in Table VII.

$\mathrm{FEV}_{1 \cdot 0} / \mathrm{FVC} \%$ cannot be predicted from age $\vec{\omega}$ or height in this group because the regression $\overrightarrow{\vec{x}}$ coefficients, simple and multiple, of $\mathrm{FEV}_{1 \cdot 0} / \times$ FVC $\%$ on age and height are not significantly different from zero.

\section{DISCUSSION}

The results of the present study provide values $\bar{C}$ for ventilatory function of 'normal' male West Pakistani industrial workers in the U.K. which can be used as standards and can also serve as a baseline for a long-term follow-up of this group.

Some authors have reported a greater effect of N age on the ventilatory capacity of smokers as compared to that of non-smokers (Sluis-Cremer and Sichel, 1968 ; Edelman et al., 1966 ; Ferris, 긍 Anderson, and Zickmantel, 1965). This could be due to the inclusion of a relatively high percen- $\mathbb{Q}$ age of smokers with a long history of heavy smoking. In our study, however, it was found $\frac{O}{3}$ that the effect of age on the indices of ventila- $\frac{\supset}{5}$ tory capacity of smokers was not different from

T A B L E V I

ZERO ORDER CORRELATION COEFFICIENTS FOR YARIABLES TAKEN IN PAIRS FOR 129 'NORMAL' SUBJECTS AGED 16 TO 24 YEARS

\begin{tabular}{|c|c|c|c|c|c|c|c|c|}
\hline & FVC & $\mathrm{FEV}_{1 \cdot 0}$ & $\frac{\text { FEV }_{1.0}}{\text { FVC }} \%$ & PEFR & Age & $\begin{array}{c}\text { Standing } \\
\text { Height }\end{array}$ & $\begin{array}{l}\text { Sitting } \\
\text { Height }\end{array}$ & Weight \\
\hline $\begin{array}{l}\text { FVC } \\
\text { FEV }_{1 \cdot 0}\end{array}$ & 1 & $\begin{array}{l}0 \cdot 97 \\
1\end{array}$ & $\begin{array}{r}-0.01 \\
0.24\end{array}$ & $\begin{array}{l}0.79 \\
0.80\end{array}$ & $\begin{array}{l}0 \cdot 25 \\
0 \cdot 21\end{array}$ & $\begin{array}{l}0.80 \\
0.80\end{array}$ & $\begin{array}{l}0.76 \\
0.73\end{array}$ & $\begin{array}{l}0.42 \\
0.36\end{array}$ \\
\hline $\mathrm{FEV}_{1 \cdot 0} / \mathrm{FVC}^{\circ} \%$ & & & 1 & $0 \cdot 13$ & -0.14 & 0.08 & $-0 \cdot 05$ & $-0 \cdot 18$ \\
\hline $\begin{array}{l}\text { PEFR } \\
\text { Age } \\
\text { Standing height } \\
\text { Sitting height } \\
\text { Weight }\end{array}$ & & & & 1 & $\begin{array}{l}0 \cdot 36 \\
1\end{array}$ & $\begin{array}{c}0.60 \\
0 \cdot 23 \\
1\end{array}$ & $\begin{array}{l}0 \cdot 64 \\
0 \cdot 25 \\
0 \cdot 82 \\
1\end{array}$ & $\begin{array}{l}0.41 \\
0.21 \\
0.48 \\
0.62 \\
1\end{array}$ \\
\hline
\end{tabular}

With 129 pairs of data the confidence level is $99 \%$ at about $r=0.23$; values of $r$ not statistically significant at this level in bold type.

T A B L E V I I

REGRESSION OF VENTITORY CAPACITY ON AGE AND STANDING HEIGHT FOR 129 'NORMAL' SUBJECTS AGED 16 TO' 24 YEARS

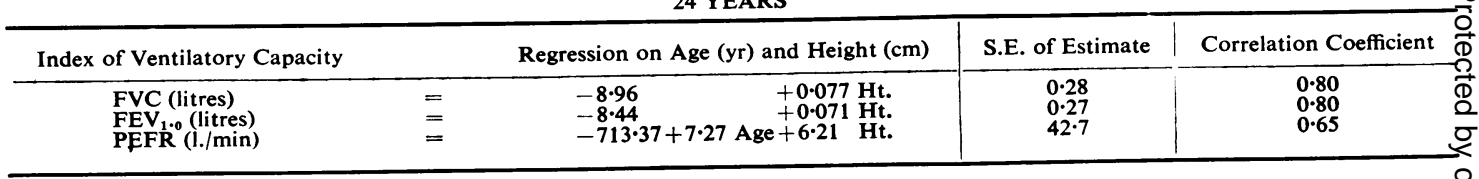


that of non-smokers $(P>0 \cdot 1)$. A possible reason for this is that of 163 who smoked, $136(83 \%)$ had smoked fewer than 10 cigarettes per day (light smokers); 23 (14\%) smoked 10 to 20 cigarettes per day (moderate smokers); and only $4(2 \%)$ smoked more than 20 cigarettes per day (heavy smokers) (see Table VIII). In addition to

\section{T A B L E V I I I}

NUMBER OF SMOKERS IN EACH CATEGORY OF SMOKING WITH PERIOD OF SMOKING IN INDUSTRIAL WORKERS (W. PAKISTAN) IN THE MANCHESTER AREA (U.K.)

\begin{tabular}{l|rrrrr|rr}
\hline & \multicolumn{5}{|c|}{ Period of Smoking (yr.) } & \multicolumn{2}{c}{ Smokers } \\
\multicolumn{1}{c|}{$\begin{array}{c}\text { Smoking } \\
\text { Habit }\end{array}$} & $1-4$ & $5-9$ & $10-14$ & $15-19$ & $20-24$ & No. & $\%$ \\
\hline $\begin{array}{l}\text { Light } \\
(1-9 \text { cig/day) }\end{array}$ & 73 & 26 & 20 & 9 & 8 & 136 & 83 \\
$\begin{array}{l}\text { Moderate } \\
(10-20 \text { cig/day) }\end{array}$ & 2 & 2 & 9 & 6 & 4 & 23 & 14 \\
$\begin{array}{l}\text { Heavy } \\
>20 \text { cig/day) }\end{array}$ & 1 & - & 2 & 1 & - & 4 & 2 \\
\hline Total & 76 & 28 & 31 & 16 & 12 & 163 & 99 \\
\hline
\end{tabular}

this, $104(64 \%)$ had smoked for less than 10 years. Smoking is, therefore, unlikely to have caused a deleterious effect on the ventilatory capacity. Similarly, a history of exposure to dust did not produce any adverse effect on the various indices of ventilatory capacity. This, again, was probably due to the short period of dust exposure. In no case did the dust exposure extend beyond five years and in 76 subjects $(52 \%)$ it was less than five years. Furthermore, the sub- jects in our study were 'normal', that is, they did not admit to persistent cough and phlegm in answer to questions 6 and 10 of the MRC questionnaire on respiratory symptoms.

In our sample, the ventilatory capacity reached its maximum between the ages of 25 and 30 years. This is in general agreement with the findings of Berglund and his co-workers (1963) and Needham, Rogan, and McDonald (1954).

Our results may be compared with those reported by other workers. As no comparable study on this ethnic group is available, the comparisons are made with the data obtained from the studies made on Caucasian and Negro populations, and on one group of Asian Indians living in Guyana. The mean age and height of the present study for the group aged 25 to 60 years have been used to predict the values of FVC, $\mathrm{FEV}_{1 \cdot 0}, \mathrm{FEV}_{1 \cdot 0} / \mathrm{FVC} \%$, and PEFR on the basis of the regressions obtained by the other authors and are compared in Table IX.

The standard errors of estimate for FVC, FEV $_{1 \cdot 0}$, and PEFR in our regression equations are comparable with those found by other workers. The regression coefficients on age for FVC and $\mathrm{FEV}_{1.0}$ in the present study are similar to those found by Lowe and his co-workers (1968) and Cotes, Rossiter, Higgins, and Gilson (1966). This may be because all these surveys were on industrial subjects. The regression coefficients on age for these indices in the studies of

T A B L E IX

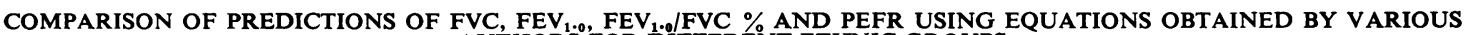
AUTHORS FOR DIFFERENT ETHNIC GROUPS

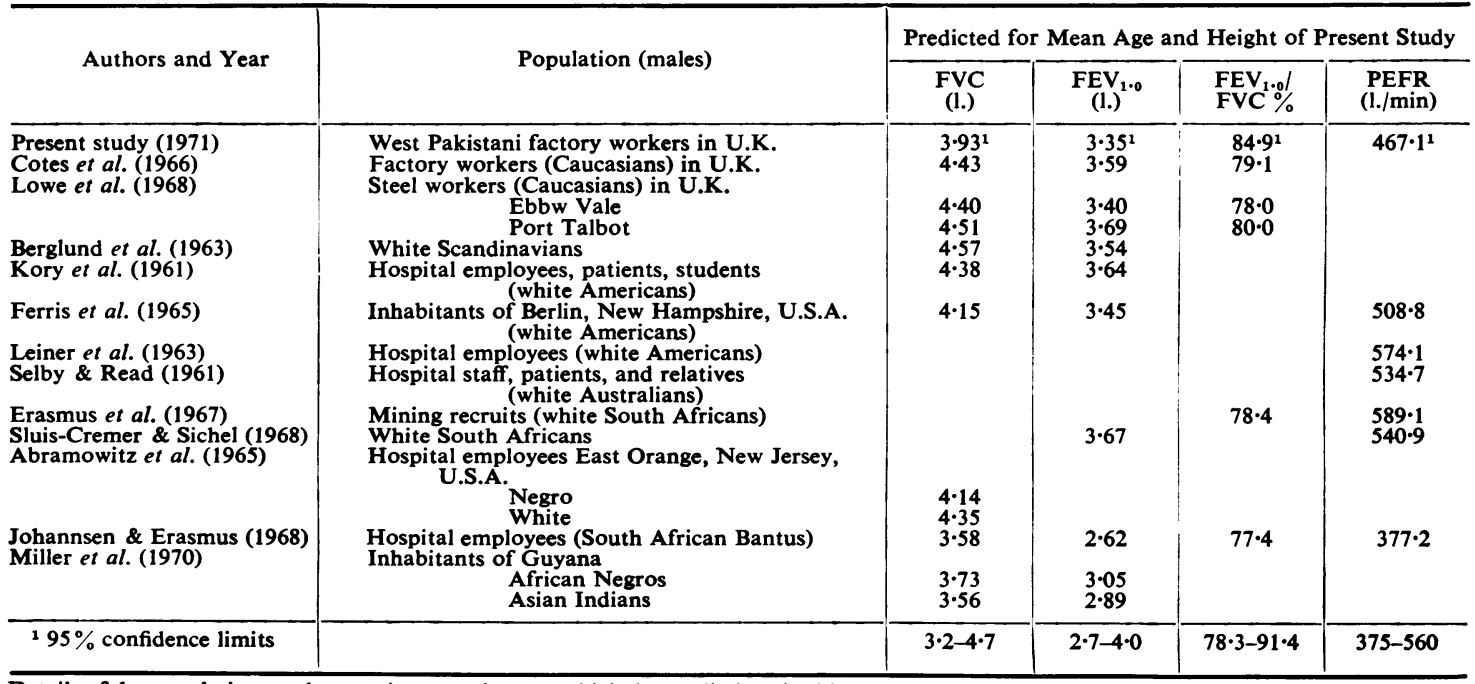

Details of the populations and regression equations on which the predictions in this table are based can be obtained from the original publications or from the authors of this paper. 
Ferris et al. (1965), Berglund and his colleagues (1963), and Kory, Callaghan, Boren, and Syner (1961) tend to be lower and are close to one another. This is probably due to their inclusion of non-industrial subjects.

The regression coefficients of FVC and FEV 1.0 on standing height in the present study are higher than all but one of those from which Table IX is derived or those published elsewhere (Hearn, 1968 ; Hunt quoted by Cotes, 1968).

In this study and, with one exception, in all the other studies included in Table IX the regression coefficient of $\mathrm{FEV}_{1.0}$ on age is slightly higher than that of FVC on age in the same study. The exception is Miller's study of Africans and Indians living in Guyana where the regression coefficients are the same (Miller et al., 1970)

The predicted FVC of the present study is lower than the values obtained from the Caucasian populations. It is somewhat lower than the value predicted by Abramowitz et al. (1965) for a group of Negro hospital employees in the United States of America, but higher than the values predicted by Miller for Negroes and for Indians of Asian origin living in Guyana and by Johannsen and Erasmus (1968) for Bantu Negroes in South Africa.

The predicted $\mathrm{FEV}_{1.0}$ of the various studies follow a pattern not unlike that for the predicted FVC. The values for the Caucasian populations are somewhat higher than the predicted $\mathrm{FEV}_{1.0}$ of the present study, which is in turn higher than those for the Negro and Indian populations in Guyana. The value for the Bantu populations in South Africa is lowest of all.

The predicted $\mathrm{FEV}_{1.0} / \mathrm{FVC} \%$ of the present study is also compared with the predicted percentage of this ratio based on the regressions on age only of the other workers (Table IX). It is interesting to note that our results for this ratio are higher than any calculated from the results of other workers. The significant effect of age $(P<0.001)$ and insignificant effect of height $(P<$ $0 \cdot 1)$ on this ratio are also, in general, similar to those found in other surveys (Cotes et al., 1966 ; Lowe et al., 1968; Erasmus, VanDoorn, and Heyns, 1967; Johannsen and Erasmus, 1968).

Predicted values of PEFR on the basis of the regressions obtained by different authors are also shown in Table IX. All the predictions of PEFR quoted are based on regressions on age and height, with the exception of that of Erasmus and his associates (1967), who found no significant correlation with age in their young healthy sample. The predicted values of PEFR also point towards ethnic differences in that PEFR values predicted from our equation tend to be lower than those of Caucasian males and higher than those of Bantu males.

Part of this work formed part of a thesis submitted for the degree of M.Sc. by one of us (M.A.M.) to the University of Manchester.

This work was carried out during the tenure of a WHO Fellowship by Dr. M. A. Malik. We should like to thank the management and workers at the mills and factories for their willing help, and the British Cotton Growing Association for providing the mobile laboratory. Particularly, we are indebted to $\mathrm{Mr}$. Iqbal, B.A., for his valuable advice and painstaking work during the translation of the MRC questionnaire into Urdu and to Mr. T. C. Sharpe of the Medical $c$ Computing Unit of this University for programming.

\section{REFERENCES}

Abramowitz, S., Leiner, G. C., Lewis, W. A., and Small, M. J. (1965). Vital capacity in the Negro. Amer. Rev. resp. Dis., 92, 287.,

Berglund, E., Birath, G., Bjure, J., Grimby, G., Kjellmer, I., Sandqvist, L., and Söderholm, B. (1963). Spirometric studies in normal subjects between 7 and 70 years of age. Acta med. scand., 173, 185.

Cotes, J. E. (1968). Lung Function Assessment and Application in Medicine, pp. 356-359 and p. 372. Blackwell Scientific Publications, Oxford.

- Rossiter, C. E., Higgins, I. T. T., and Gilson, J. C. (1966). Average normal values for the forced expiratory volume in white Caucasian males. Brit. med.J., 1, 1016.

Edelman, N. H., Mittman, C., Norris, A. H., Cohen, B. H., and Shock, N. W. (1966). The effects of cigarette smoking upon spirometric performance of community dwelling men. Amer. Rev. resp. Dis., 94, 421.

Erasmus, L. D., VanDoorn, H., and Heyns, A. J. (1967). Initial pulmonary function testing in gold miners in Johannesburg. S. Afr. med. J., 41, 1088.

Ferris, B. G., Anderson, D. O., and Zickmantel, R. (1965). Prediction values for screening tests of pulmonary function. Amer. Rev. resp. Dis., 91, 252.

Gandevia, B., and Hugh-Jones, P. (1957). Terminology for 윽 measurements of ventilatory capacity. Thorax, 12, 290.

Hearn, C. E. D. (1968). Bagassosis: an epidemiological, environmental, and clinical survey. Brit. J. industr. Med., 25, 267.

Johannsen, Z. M., and Erasmus, L. D. (1968). Clinical spirometry in normal Bantu. Amer. Rev. resp. Dis., 97, 585. O

Kory, R. C., Callaghan, R., Boren, H. G., and Syner, J. C. స (1961). The veterans administration-army co-operative $\sigma$ study of pulmonary function. 1. Clinical spirometry in normal men. Amer. J. Med., 30, 243.

Leiner, G. C., Abramowitz, S., Small, M. J., Stenby, V. B., $\mathbb{D}$ and Lewis, W. A. (1963). Expiratory peak flow rate. Standard values for normal subjects. Amer. Rev. resp. T Dis., 88, 644.

Lowe, C. R., Pelmear, P. L., Campbell, H., Hitchens, R. A. $\stackrel{\vec{D}}{\circ}$ N., Khosla, T., and King, T. C. (1968). Bronchitis in $\frac{O}{\mathbb{D}}$ two integrated steel works. 1 . Ventilatory capacity, age, $\varrho$ and physique of non-bronchitic men. Brit. J. prev. soc. Med., 22, 1. 
Malik, M. A. (1971). M.Sc. Thesis, Manchester University. Medical Research Council (1960). Standardized questionnaires on respiratory symptoms. Brit. med.J. 2, 1665.

(1965). Definition and classification of chronic bronchitis. Lancet, 1, 775.

Miller, G. J., Ashcroft, M. T., Swan, A. V., and Beadnell, H. M. S. G. (1970). Ethnic variation in forced expiratory volume and forced vital capacity of African and Indian adults in Guyana. Amer. Rev. resp. Dis., $102,979$.

Myers, J. A. (1925). Vital Capacity of the Lungs, pp. 32-35. Williams and Wilkins, Baltimore.

Needham, C. D., Rogan, M. C., and McDonald, I. (1954). Normal standards for lung volumes, intra-pulmonary gas-mixing and maximum breathing capacity. Thorax, 9, 313.

Olsen, H. C., and Gilson, J. C. (1960). Respiratory symptoms, bronchitis and ventilatory capacity in men: an AngloDanish comparison. Brit. med. J., 1, 450.
Pappenheimer, J. R. (1950). Standardization of definitions and symbols in respiratory physiology. Fed. Proc., 9, 602 .

Selby, T., and Read, J. (1961). Maximal expiratory flow rates in Australian adults. Aust. Ann. Med., 10, 49.

Sluis-Cremer, G. K., and Sichel, H. S. (1968). Ventilatory function in males in a Witwatersrand town. Amer. Rev. resp. Dis., 98, 229.

Walker, D. D., Archibald, R. M., and Attfield, M. D. (1971). Bronchitis in men employed in the coke industry. Brit. J. industr. Med., 28, 358.

Weiner, J. S., and Lourie, J. A. (1969). Human Biology-A Guide to Field Methods. Blackwell Scientific Publications, Oxford.

Wright, B. M., and McKerrow, C. B. (1959). Maximum forced expiratory flow rate as a measure of ventilatory capacity, with a description of a new portable instrument for measuring it. Brit. med. J., 2, 1041. 